nearly $£ 2,000,000$, and more than 6,000 acres of land has been preserved for all time for recreation. In this as in other enterprises the Trustees have hastened that enlargement of the spheres of action of local authorities foreseen by Mr. Carnegie. As they point out in the review contributed by them to "The Trusts and their Work", there has been since the Great War a growing recognition by local authorities that certain activities of a pioneer kind are more effectively administered by volunteer workers than by the official machine. This has led to enlightened experiments in which the Trustees have participated and have assisted voluntary bodies to earn Government grants.

Of post-War developments in the social life of the people of the United Kingdom there is one that would, beyond all others, had he lived to see it, have excited Mr. Carnegie's interest and aroused in him, as an apostle of sweetness and light, the gravest concern-the gigantic growth of the cinematograph industry. The inquiry by the Commission on Edueational and Cultural Films and the resulting report entitled "The Film in Education", which led to the establishment in 1933 of the British Film Institute, were financed by the Trustees to the extent of $£ 6,100$. In the face of their splendid record of work accomplished, it would be hypercritical to suggest that the Trustees might have hastened the advent of that Institute, but one cannot help wishing that it had come into existence ten years earlier.

At the dawn of the twentieth century, Mr. Carnegie was already sixty-five years of age, and many of his views on social problems were, of course, coloured by a social background as far removed from ours of to-day as was that from the Middle Ages. But these few notes on "The Trusts and their Work" are sufficient to show that he is very far indeed from being a spent or retro-active force.

\title{
Resolutions of the Sixth International Botanical Congress
}

$\mathrm{T}$ HE Executive Committee of the Sixth International Botanical Congress recently held at Amsterdam (see Nature of November 12) has issued the draft of the general and sectional resolutions passed at the final plenary meeting.

It was agreed that the Botanical Section of the International Union of Biological Sciences should act as an administrative link between successive International Botanical Congresses, and should be authorised to carry through the resolutions passed. The Union was asked to approach the various Governments in order to obtain inexpensive facilities for the exchange by post or otherwise of collections of dried plants.

The attention of public and scientific bodies was directed to the danger of destruction of natural vegetation in tropical and subtropical countries by brushwood and prairie fires and by human agency. The necessity of permanent natural reserves, and of the maintenance of an adequate proportion of natural forest areas was emphasised, and a committee was set up to study associated problems and to inform the Governments concerned. The importance of international discussions and action in the campaign against plant diseases and insect pests was stressedthis resolution is to be brought to the attention of the League of Nations.
A committee was appointed to olaborate proposals for a classification of climates from a phytogeographic point of view ; the committee on the description and nomenclature of plant viruses was ompowerod to continue its work; and application is to be made to the International Committee for Genetical Congresses for the appointment of a committee to clarify and improve the terminology of geneties and cytology. Propositions in favour of the proparation. of a new "Phytography"- - a compilation of lists of the collections represented in the larger herbaria-and of an "International Dictionary of Botanical Terminology", were approved; also the desirability of photographing the Linnæan type specimens at the Linnean Society and the British Museum.

Appreciation of the admirable work of the Centraalbureau voor Sehimmelcultures at Baarn was expressed, and also grave concern at the present financial difficulties of what is essentially an international institution. The editorial committee of the International Rules of Botanical Nomonclature, third ed. (1935) was thanked for its work; the decisions of the Section of Taxonomy and Nomenclature concerning modifications of the rules were accepted, and the appointment of the standing committees of the Section was sanctioned.

\section{Progressive Traffic Signals in London}

$I^{\mathrm{N}}$ the engineering supplement to the Siemens Magazine for November, Mr. F. G. Tyack gives a full account of the 'Autoflex progressive system' of traffic control which the experience of the last two years has shown to be very satisfactory in certain London streets. The problem is a difficult one, but its analogy to the corresponding problem of controlling 'the traffic' in telephony has been a great help in finding a solution. For the first time the theory of probability has been applied to street traffic problems. Mathematicians will be interested to learn that the method of 'least squares' is applied to the plotting of time and distance diagrams.
Motorists are well aware that one of the principal difficulties experienced by traffic police at complex intersections, or along busy thoroughfares, is efficient co-operation. They are often not in sight of one another and are generally fully occupied with the control of traffic in their immediate vicinity. Electrical signalling has been found to be the most convenient means of controlling the traffic.

In the flexible progressive system, there is a large number of 'local' traffic controlling devices at each intersection throughout the controlled area. These are linked electrically to a master controller which co-ordinates the indications given to the traffic and 